\title{
PATHOGENIC LACTOBACILLI
}

\author{
M. Elisabeth Sharpe, L. R. Hill and S. P. Lapage \\ National Institute for Research in Dairying, Shinfield, Reading and \\ National Collection of Type Cultures, Central Public Health Laboratory, Colindale, London
}

LACTOBACILLI are generally considered to be non-pathogenic except in dental caries (Wilson and Miles, 1964; Attebery and Finegold, 1970). However, in three cases lactobacilli have been incriminated as the possible cause of human infections: Marschall (1938) described a case of endocarditis due to "Döderlein's bacillus" and Biocca and Seppilli (1947) reported two fatal cases of endocarditis from which strains of Lactobacillus acidophilus were isolated. Sims (1964) described a mucoid mutant of $L$. casei var. rhamnosus that was pathogenic to mice and rats. The parent, non-mucoid strain was not pathogenic. Rosan and Hammond (1965) showed that a capsulated variant of another strain of $L$. casei had enhanced virulence in rabbits in comparison with a noncapsulated variant. Howitt and Van Meter (1930) produced joint lesions in rabbits by the intravenous injections of living aciduric lactobacilli both of dental and of intestinal origin.

Lactobacilli generally grow very poorly, if at all, on media such as blood agar or nutrient agar, and their presence in clinical specimens may frequently be missed. We describe here seven instances in which lactobacilli, sent to the National Collection of Type Cultures (NCTC) for identification, were implicated as possible pathogens.

\section{Case reports}

Case 1. A 31-yr-old man with rheumatic valvular disease had a clinical condition suggesting subacute bacterial endocarditis. A lactobacillus was isolated from three blood cultures.

Case 2. A 32-yr-old Chinese man died from a condition resembling erysipeloid. A lactobacillus was isolated from a lymph-node.

Case 3. A 17-yr-old woman with Marfan's syndrome and a previous history at $5 \mathrm{yr}$ of age of rheumatic fever, had a patent interventricular septum. Septicaemia followed a tooth extraction and a lactobacillus was isolated from six of seven blood cultures. The patient recovered after treatment with penicillin, probenecid and streptomycin.

Case 4. A 36-yr-old woman had a low-grade fever of 2 weeks' duration which was diagnosed clinically as subacute bacterial endocarditis. There was a history of coarctation of the aorta (resected $9 \mathrm{yr}$ previously), and an aneurysm of the ascending aorta $7 \mathrm{yr}$ previously, but there was no history of rheumatic fever. Seven of eight blood cultures yielded a lactobacillus.

Case 5. A 34-yr-old female had a throat infection and a membranous

Received 6 Oct. 1972; accepted 6 Oct. 1972.

J. MED. MICROBIOL.-VOL. 6 (1973) 
tonsillar exudate which was examined to exclude diphtheria. The largest piece of the membrane examined measured about $4 \times 3 \times 1 \mathrm{~cm}$. Histologically, nonbranching Gram-positive bacilli were seen. No corynebacteria or streptococci were isolated on blood agar and tellurite blood agar. On Sabouraud agar, incubated anaerobically, a lactobacillus grew. However, the clinical significance of this strain was doubtful.

Case 6. A 64-yr-old male had an adeno-carcinoma of the stomach involving the cardio-oesophageal junction. Gastrostomy was performed and cardiooesophagectomy 18 days later. At the second operation, an abscess was found behind the site of the gastrostomy, and this yielded an anaerobic streptococcus. Ten days after the second operation, rigors and a temperature of $38^{\circ} \mathrm{C}$ developed, and a lactobacillus was isolated from blood cultures taken on 2 successive days. The patient became apyrexial within 4 days of gentamicin therapy and he recovered from the septicaemia.

Case 7. An infant died from what was suspected to be septicaemia and meningitis. The spleen and blood were both sterile. The gut yielded the normal bacterial flora post mortem and the only abnormal pathological finding was that the brain tissue was swollen and hyperaemic. There were no postmortem signs of meningitis. Direct staining of brain tissue revealed large numbers of Gram-positive bacilli. A lactobacillus was isolated from the tissue; but the clinical importance of this strain is in doubt.

A summary of the above cases is given in table $I$.

MATERIALS AND METHODS

Organisms. Eight strains have been examined, seven of which were from the above described cases of infection. In addition and for comparison, NCTC no. 10302 Lactobacillus casei var. rhamnosus, was investigated. This capsulated laboratory mutant was obtained from an oral strain originally from an edentulous adult and was described, and deposited in the NCTC, by Sims (1964).

Bacteriological investigations. The strains were examined both at Reading (NIRD) and Colindale (NCTC). At Reading the methods used were those of Rogosa and Sharpe (1959) and Sharpe, Davidson and Baddiley (1964), while at Colindale the methods given in Cowan and Steel (1965) were followed; for lactobacilli, these are largely based on those of Rogosa and Sharpe. The features of the strains that were recorded were the following.

At Reading (NIRD): colonial and microscopic appearance on the medium of de Man, Rogosa and Sharpe (1960, MRS agar); ability to grow in the selective lactobacillus acetate medium of Rogosa, Mitchell and Wiseman (1951); aerobic growth at $15^{\circ}, 45^{\circ}$ and $48^{\circ} \mathrm{C}$; catalase; production of gas from glucose, and gluconate; production of ammonia from arginine; final $p \mathrm{H}$ in broth; action in yeast glucose litmus milk; aesculin hydrolysis and fermentation of a wide range of carbohydrates. Ring-precipitin tests were done with acid extracts of the organisms and specific antisera to Lactobacillus casei group B and group C. No other antisera were available.

At Colindale (NCTC): colonial and microscopic appearance; growth aerobically and anaerobically; growth at $22^{\circ}, 30^{\circ}, 37^{\circ}$ and $45^{\circ} \mathrm{C}$; growth on blood agar, on tomatojuice agar, and on MRS agar; Hugh and Leifson's (1953) O-F test; production of gas from glucose (Gibson and Abdel-Malek, 1945); catalase; oxidase; citrate utilisation; production of indole; methyl red; acetoin production; hydrogen-sulphide production; nitrate reduction; action on bromcresol-purple milk; liquefaction of gelatin; production of ammonia from arginine; urease activity; casein digestion; starch hydrolysis; oxidation of gluconate; utilisation of malonate; phenylalanine deamination; LV (lecithovitellin) reaction and production of acid from a wide range of carbohydrates. 


\section{RESULTS}

The recognition of Lactobacillus species was made mainly on the results of carbohydrate fermentation tests and serology, and the strains were identified as shown in table I.

TABLE I

Sources of the strains of lactobacilli examined

\begin{tabular}{|c|c|c|c|}
\hline $\begin{array}{c}\text { Case } \\
\text { number }\end{array}$ & $\begin{array}{l}\text { Age, sex and } \\
\text { clinical condition }\end{array}$ & Isolation from & Received from \\
\hline \multicolumn{4}{|c|}{ L. casei var. rhamnosus } \\
\hline 1 & $\begin{array}{l}31 \text { yr, M. Subacute bac- } \\
\text { terial endocarditis }\end{array}$ & blood cultures $(3 / 3)^{*}$ & $\begin{array}{l}\text { W. M. Edgar, Bradford } \\
\text { in } 1964\end{array}$ \\
\hline 2 & $\begin{array}{l}32 \text { yr, M. Erysipeloid } \\
\text { condition (fatal) }\end{array}$ & lymph-node & $\begin{array}{l}\text { J. Kennedy, Newcastle- } \\
\text { upon-Tyne in } 1970\end{array}$ \\
\hline 3 & $\begin{array}{l}17 \mathrm{yr}, \mathrm{F} \text {. Septicaemia } \\
\text { following dental extrac- } \\
\text { tion. Congenital heart } \\
\text { disease. }\end{array}$ & blood cultures $(6 / 7)$ & $\begin{array}{l}\text { W. H. A. Picton, } \\
\text { Uxbridge in } 1970\end{array}$ \\
\hline 4 & $\begin{array}{l}36 \mathrm{yr}, \mathrm{F} \text {. Subacute bac- } \\
\text { terial endocarditis }\end{array}$ & blood cultures $(7 / 8)$ & $\begin{array}{l}\text { C. Krishnan, Toronto in } \\
1970\end{array}$ \\
\hline NCTC10302 & ... & $\begin{array}{l}\text { parent strain from saliva } \\
\text { (laboratory mutant) }\end{array}$ & W. Sims, London in 1962 \\
\hline L. plantarum & $34 \mathrm{yr}, \mathrm{F}$. Throat infection & tonsillar membrane & $\begin{array}{l}\text { C. D. Plows, Sheffield in } \\
1968\end{array}$ \\
\hline 6 & $\begin{array}{l}64 \text { yr, M. Septicaemia } \\
\text { following gastrostomy } \\
\text { and cardio-oesophagec- } \\
\text { tomy }\end{array}$ & blood cultures $(6 / 6)$ & $\begin{array}{l}\text { L. Parker, Manchester in } \\
1972\end{array}$ \\
\hline L. sp. subgen & $\begin{array}{l}\text { us Thermobacterium } \\
\text { Infant. Suspected septi- } \\
\text { caemia and meningitis }\end{array}$ & brain tissue & $\begin{array}{l}\text { R. D. Gray, Newport, } \\
\text { Mon. in } 1970\end{array}$ \\
\hline
\end{tabular}

* Number positive/number examined.

In their general properties, the seven field strains were very similar. They were all Gram-positive, non-motile rods, all grew in acetate medium, though better anaerobically than aerobically, and better on either MRS or tomato juice agar than on blood agar. They all grew over the range of temperature $30^{\circ}$ to $45^{\circ} \mathrm{C}$; growth at $15^{\circ}, 22^{\circ}$ and $48^{\circ} \mathrm{C}$ is recorded in table II. Results for terminal $p \mathrm{H}$ in broth and gas production from gluconate are also shown in this table.

Aesculin was hydrolysed by all the strains, and acid and clot were produced in bromcresol-purple milk. The following biochemical tests were negative: catalase, oxidase, citrate, indole, methyl red, acetoin, hydrogen sulphide, nitrate 
TABLe II

Biological properties of the strains of lactobacilli

\begin{tabular}{|c|c|c|c|c|c|c|c|c|}
\hline \multirow{3}{*}{ Property } & \multicolumn{8}{|c|}{ Results of tests on } \\
\hline & \multicolumn{5}{|c|}{ Lactobacillus casei var. rhamnosus number } & \multicolumn{2}{|c|}{$\begin{array}{l}\text { L. plantarum } \\
\text { number }\end{array}$} & \multirow{2}{*}{$\begin{array}{c}\text { Thermo- } \\
\text { bacterium } \\
\text { number } \\
7\end{array}$} \\
\hline & $\begin{array}{l}\text { NCTC } \\
10302\end{array}$ & 1 & 2 & 3 & 4 & 5 & 6 & \\
\hline Growth at $15^{\circ} \mathrm{C}$ & + & + & + & + & + & + & + & - \\
\hline $22^{\circ} \mathrm{C}$ & + & + & + & + & + & + & + & - \\
\hline $30-45^{\circ} \mathrm{C}$ & + & + & 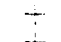 & + & + & + & + & + \\
\hline Terminal $p \mathrm{H}$ in broth & $3 \cdot 8$ & $3 \cdot 5$ & $3 \cdot 5$ & $\overline{3 \cdot 5}$ & 3.9 & $\overline{3.6}$ & $\overline{3 \cdot 7}$ & $\overline{3.9}$ \\
\hline Gas from gluconate & + & + & + & + & + & + & + & - \\
\hline
\end{tabular}

$+=$ Positive result $;-=$ negative result.

TABLE III

Fermentation tests on the strains of lactobacilli

\begin{tabular}{|c|c|c|c|c|c|c|c|c|}
\hline \multirow{3}{*}{ Carbohydrate } & \multicolumn{8}{|c|}{ Results of tests on } \\
\hline & \multicolumn{5}{|c|}{ Lactobacillus casei var. rhamnosus number } & \multicolumn{2}{|c|}{$\begin{array}{l}\text { L. plantarum } \\
\text { number }\end{array}$} & \multirow{2}{*}{$\begin{array}{c}\text { Thermo- } \\
\text { bacterium } \\
\text { number } \\
7\end{array}$} \\
\hline & $\begin{array}{l}\text { NCTC } \\
10302\end{array}$ & 1 & 2 & 3 & 4 & 5 & 6 & \\
\hline Xylose & - & - & - & - & - & - & - & - \\
\hline Arabinose & - & - & - & - & - & - & + & + \\
\hline Ribose* & + & + & + & + & + & + & + & + \\
\hline Rhamnose & + & + & + & + & + & - & $+(-)$ & - \\
\hline Fructose* & + & + & + & + & + & + & + & + \\
\hline Glucose & + & + & + & $t$ & + & + & + & + \\
\hline Mannose & + & + & + & + & + & + & + & + \\
\hline Galactose & + & + & $+(-)$ & + & + & + & + & + \\
\hline Sucrose & + & + & + & - & $+(-)$ & + & $+(-)$ & + \\
\hline Trehalose & + & + & + & + & + & + & + & - \\
\hline Maltose & + & + & + & + & - & + & + & + \\
\hline Cellobiose & + & + & + & + & + & + & + & + \\
\hline Melibiose $^{*}$ & - & - & - & - & - & + & + & + \\
\hline Lactose & + & + & + & + & + & + & $t$ & + \\
\hline Melezitose* & + & - & + & - & + & + & + & - \\
\hline Raffinose & - & - & - & - & - & $+(-)$ & + & + \\
\hline Starch $\dagger$ & NT & NT & - & - & - & NT & - & I \\
\hline Glycerol & + & + & + & + & + & + & - & - \\
\hline Adonitol $\dagger$ & - & - & - & - & - & NT & - & - \\
\hline Sorbitol & + & + & + & + & $+(-)$ & $+(-)$ & + & - \\
\hline Mannitol & + & + & + & + & + & + & + & - \\
\hline Dulcitol $\dagger$ & NT & - & - & + & - & NT & - & - \\
\hline Inositol & - & NT & - & - & - & - & - & - \\
\hline Salicin & + & + & + & + & + & + & + & + \\
\hline Amygdalin* & + & + & + & + & + & + & + & + \\
\hline
\end{tabular}

* Tested at NIRD only.

$\dagger$ Tested at NCTC only.

$+=$ Positive result; $--=$ negative result; NT $=$ not tested. (Unmarked carbohydrates tested at NCTC and NIRD; NCTC result, if different, given in parentheses.) 
reduction, gelatin, oxidation of gluconate, malonate, phenylalanine, ammonia from arginine, LV, urease, casein and starch hydrolysis.

The strains gave a fermentative reaction in the Hugh and Leifson's O-F test, although two strains (from cases 2 and 3) gave only slight acid production in this medium. Gas was not produced in the Gibson and Abdel-Malek test and the strains were therefore homofermentative. The results obtained for acid production from various carbohydrates are given in table III.

Extracts of the four strains of $L$. casei var. rhamnosus all reacted with group $\mathrm{C}$ antiserum, but not with the group $\mathrm{B}$ antiserum. Extracts of the other three strains failed to react with either antiserum.

\section{Discussion}

These seven case reports indicate that lactobacilli cannot always be dismissed as non-pathogenic. In cases 1, 3 and 4 the patients had histories of heart disease and the lactobacilli were isolated from blood cultures. In case 2 , the source of the lactobacillus isolated was a lymph-node and this may suggest generalised infection. In case 5, only the lactobacillus was found in the tonsillar membrane, and in case 7 the only abnormal finding at necropsy was hyperaemia and swelling of the brain tissue, from which the lactobacillus was obtained. The pathogenic role of strains 5, 6 and 7 (two strains of L. plantarum and one of Thermobacterium sp.) is uncertain; organisms taken in with the diet may have proliferated, in case 5 in the throat, in case 6 in the region of the stomach after extensive surgical interference, and in case 7 post mortem.

The incrimination of $L$. casei var. rhamnosus as a pathogen is on more certain grounds, because three of the strains isolated in this series came from blood cultures of clinical cases of endocarditis. Sims (1964) and Rosan and Hammond (1965) have shown by means of animal experiments that $L$. casei var. rhamnosus and $L$. casei can cause disease.

The strains of $L$. acidophilus reported by Marschall (1938) and by Biocca and Seppilli (1947) (whose strains according to Sims may have been $L$. plantarum) were also from cases of endocarditis, suggesting that Lactobacillus species other than $L$. case $i$ may occasionally be pathogenic.

The identification of six of the strains did not present any difficulty. The strain of $L$. casei var. rhamnosus from case 4 was atypical in failing to ferment maltose. The strain from case 5 was a typical strain of $L$. plantarum except in that it was able to grow at $45^{\circ} \mathrm{C}$ as well as at $15^{\circ} \mathrm{C}$. However, the strain from case 7 , which was placed in the subgenus Thermobacterium by being homofermentative, by its growth temperatures, and by its inability to form gas from gluconate (Rogosa, 1970) could not be identified further. Its carbohydratefermentation pattern is closest to that of L. acidophilus, but it differs from this species in that it ferments ribose and arabinose but not trehalose.

\section{SUMMARY}

Lactobacilli are generally not thought of as pathogenic, except in dental caries. Seven strains of lactobacilli obtained from various clinical conditions were fully investigated. They were identified as four strains of $L$. casei var. 
rhamnosus, two strains of $L$. plantarum and one strain of the subgenus Thermobacterium, which could not be further identified.

Some of these strains were believed to play a pathogenic role. In three cases the lactobacilli were repeatedly isolated from blood cultures taken during life; all these proved to be L. casei var. rhamnosus.

We should like to thank Drs W. M. Edgar, R. D. Gray, J. Kennedy, C. Krishnan, L. Parker, W. H. A. Picton, and C. D. Plows for sending us their strains for identification and permission to publish their clinical information. We also acknowledge the technical assistance of Mr J. J. S. Snell and Mr B. A. Phillips.

\section{Note ADded IN Proof, 30 MAY 1973}

Three further strains of Lactobacillus have been isolated from patients. One, a strain of $L$. casei var. rhamnosus, was isolated from an empyema together with Escherichia coli and Candida albicans. The patient was a 64-yrold man who had had a previous operation for a hiatus hernia. A fistula was later found which connected the empyema space with the stomach through the diaphragm. The second, a strain of $L$. casei var. casei, was isolated from ten consecutive blood cultures from a 62-yr-old man with mitral-valve disease and suspected endocarditis. The third was an atypical strain of L. brevis, isolated from a blood culture of a 49-yr-old man who had pneumonia.

\section{REFERENCES}

Attebery, H. R., ANd Finegold, S. M. 1970. A new anaerobic blood culture system. Xth Int. Congr. Microbiol., Abstracts, 1970, p. 105.

Biocca, E., AND Seppilli, A. 1947. Human infections caused by lactobacilli. J. Infect. Dis., 81, 112.

Cowan, S. T., ANd Steel, K. J. 1965. Manual for the identification of medical bacteria, Cambridge.

Gibson, T., AND Abdel-MaleK, Y. 1945. The formation of carbon dioxide by lactic acid bacteria and Bacillus licheniformis and a cultural method of detecting the process. $J$. Dairy Res., 14, 35.

Howitt, Beatrice, AND Van Meter, Martha 1930. Lesions produced in rabbits by lactobacillus cultures. J. Infect. Dis., 46, 368.

Hugh, R., AND Leifson, E. 1953. The taxonomic significance of fermentative versus oxidative metabolism of carbohydrates by various Gram negative bacteria. J. Bact., 66, 24 .

Man, J. C. De, Rogosa, M., ANd Sharpe, M. Elisabeth 1960. A medium for the cultivation of lactobacilli. J. Appl. Bact., 23, 130.

Marschall, F. 1938. Der Döderleinsche Bacillus vaginalis als Endokarditiserreger. Zentbl. Bakt. ParasitKde, I Abt. Orig., 141, 153.

Rogosa, M. 1970. Characters used in the classification of lactobacilli. Int. J. Syst. Bact., 20, 519.

Rogosa, M., Mitchell, Joyce A., And Wiseman, R. F. 1951. A selective medium for the isolation and enumeration of oral and fecal lactobacilli. J. Bact., 62, 132.

Rogosa, M., AND Sharpe, M. Elisabeth 1959. An approach to the classification of the lactobacilli. J. Appl. Bact., 22, 329.

Rosan, B., And Hammond, B. F. 1965. Toxicity of Lactobacillus casei. J. Dent. Res., 44, 783.

Sharpe, M. Elisabeth, Davidson, A. L., And Baddiley, J. 1964. Teichoic acids and group antigens in lactobacilli. J. Gen. Microbiol., 34, 333.

Sims, W. 1964. A pathogenic lactobacillus. J. Path. Bact., 87, 99.

Wilson, G. S., AND Miles, A. A. 1964. Topley and Wilson's Principles of Bacteriology and Immunity, 5th ed., London. 